\title{
Cell reservoirs in lymph nodes infected with HIV-1 subtype E differ from subtype B: identification by combined in situ polymerase chain reaction and immunohistochemistry
}

\author{
Lertlakana Bhoopat $^{1}$, Tat S Rithaporn ${ }^{1}$, Surapan Khunamornpong ${ }^{1}$, Tanin Bhoopat ${ }^{2}$, \\ Clive R Taylor ${ }^{3}$ and Paul S Thorner ${ }^{4,5}$
}

${ }^{1}$ Department of Pathology, Faculty of Medicine, Chiang Mai University, Chiang Mai, Thailand; ${ }^{2}$ Department of Forensic Medicine Molecular Laboratory, Faculty of Medicine, Chiang Mai University, Chiang Mai, Thailand; ${ }^{3}$ Department of Pathology, University of Southern California, CA, USA; ${ }^{4}$ Division of Pathology, Hospital for Sick Children, University of Toronto, Toronto, ON, Canada and ${ }^{5}$ Department of Laboratory Medicine and Pathobiology, University of Toronto, Toronto, ON, Canada

\begin{abstract}
In Thailand, the predominant HIV subtype is E, rather than subtype B as in North America and Europe. Subtype $E$ has the ability to replicate in vitro in Langerhans cells. We hypothesized that this cell type might constitute a reservoir for the HIV virus in infected lymph nodes. We examined lymph nodes from 25 HIV-1 subtype E-infected patients to determine the immunophenotype of HIV-1-infected cells, their numbers and their distribution. The presence of HIV was detected either by in situ reverse transcriptase-polymerase chain reaction or immunoperoxidase. Cell identity was determined by double labelling using alkaline phosphatase-based immunohistochemistry. The majority of HIV-infected cells in the lymph nodes were Langerhans cells $(\mathrm{CD} 1 \mathrm{a}+\mathrm{S} 100+)$ and Langerhans-related dendritic cells $(\mathrm{p} 55+\mathrm{S} 100+)$. These cells were located in the paracortical areas of lymph nodes, with a few cells scattered at the edges of germinal centers, but were absent from germinal centers themselves, in contrast to the reported distribution of subtype B virus. In addition, multinucleated giant cells were significantly more common in HIV-infected nodes (64\%) compared to controls $(4 \%)(P=0.00002)$. In conclusion, Langerhans histiocytes and related cells are reservoirs for HIV subtype $E$ in lymph nodes. Disrupting the pathway of infection of Langerhans cells and related cells may be a viable strategy to interfere with transmission of HIV subtype $E$.
\end{abstract}

Modern Pathology (2006) 19, 255-263. doi:10.1038/modpathol.3800527; published online 2 December 2005

Keywords: HIV-1 subtype E; p24; double immunostaining; Langerhans cells; dendritic cells; lymph nodes

There are at least 11 different genotypes (clades) of HIV-1, based on differences in the envelope-coding region of the virus. Much of the knowledge of HIV infection and cellular distribution comes from studies of subtype $\mathrm{B}$ virus infection, the major subtype in the Western world. ${ }^{1}$ However, increasingly, it is recognized that HIV subtypes differ in their biologic properties ${ }^{1}$ and it is questionable whether our understanding of the transmission, pathogenesis and tissue involvement in HIV-1 subtype B infection can be generalized for all

Correspondence: Dr L Bhoopat, MD, Department of Pathology, Faculty of Medicine, Chiang Mai University, Chiang Mai 50200, Thailand.

E-mail: lbhoopat@mail.med.cmu.ac.th

Received 26 August 2005; revised 12 September 2005; accepted 16 October 2005; published online 2 December 2005 subtypes. While HIV-1 subtype E accounts for $\sim 10 \%$ of cases worldwide, in Thailand more than $90 \%$ of sexually transmitted HIV-1 cases are subtype $\mathrm{E}^{2-4}$ and heterosexual transmission is the major mode of spread via a mucosal route. ${ }^{5-7}$ It has been calculated that heterosexual transmission occurs five times more frequently per heterosexual exposure in Thailand compared to the US. ${ }^{8}$ It has therefore been suggested that there is an increased propensity for transmission of subtype $\mathrm{E}$ as opposed to subtype B during heterosexual exposure. ${ }^{8} \mathrm{~A}$ better understanding of subtype-specific behavior would facilitate the development of therapies and vaccines for the different subtypes of HIV-1 disease.

An increased ability of subtype $\mathrm{E}$ virus to replicate in epithelial Langerhans cells has been demonstrated using an in vitro system of Langerhans cells 
purified from epidermis and infected with subtype B or E virus. ${ }^{7}$ As these cells may be among the first to encounter the virus after mucosal transmission, an increased ability of the virus to grow in Langerhans cells might enhance virus transmission and could contribute to the epidemiologic findings of increased heterosexual transmission in Southeast Asia. In a previous study, we showed that Langerhans cells and related dendritic cells located in vaginal mucosa of HIV-infected patients were infected with subtype E. ${ }^{9}$ We postulated that the increased propensity for heterosexual transmission of subtype E might be related to vaginal inflammation, leading to the accumulation of Langerhans cells and related dendritic cells, which, once infected with HIV, could then act as a reservoir for further viral transmission. ${ }^{9}$

In a separate study, we noted that in lymph nodes from HIV subtype B-infected patients, the virus localized to cells within the germinal centers, demonstrating a distinctive reticular pattern by immunohistochemistry. ${ }^{10}$ In contrast, HIV subtype E was distributed differently in lymph nodes of infected patients, as clusters of cells and as individually scattered cells in the interfollicular regions, with only a few cells around the edge of germinal centers. This study was based on immunohistochemical detection of HIV and did not include identification of which cell types were infected. Hence, in the present study, we combined the use of the in situ polymerase chain reaction (PCR) with immunohistochemistry to elucidate the immunophenotypes of the cells acting as reservoirs in HIV-1 subtype E-infected lymph nodes. Based on our results with vaginal mucosal biopsies, we postulated that the cell reservoirs in lymph nodes would also be Langerhans cells and related dendritic cells.

\section{Materials and methods}

\section{Study Patients}

Chart review allowed identification of 25 HIVseropositive patients and a control group of 25 patients, all of whom had lymph node biopsies performed. The control group had not been tested for HIV serology and belonged to a 'low-risk' group with no history of other infections or autoimmune diseases. Lymph node biopsies in this group had been obtained to rule out other diseases. Clinical categories of the 25 HIV-positive patients were classified based on the 1993 US Center for Disease Control revised classification system, which is based on both clinical manifestation and CD4 lymphocyte counts. ${ }^{11}$ HIV serology was tested using a commercial ELISA assay (Abbott Laboratories, Illinois, USA) and SERODIA-HIV kit (Fujirebio Inc., Tokyo, Japan), and confirmed by Western blotting in patients in clinical categories A and B.

\section{HIV Subtyping}

HIV subtyping was carried out using the PCR on DNA extracted from peripheral blood samples and tissue sections according to published methods. ${ }^{12}$ The portion of the genome amplified included the dimerization initiation site (DIS) loop sequence present in infectious recombinant provirus. The DIS loop and flanking sequences were amplified from cell lysates by using a $27 \mathrm{bp}$ upstream (sense) primer DIS1 ( $5^{\prime}$-AAATCTCTAGCAGTGGCGCCCGAACAG-3') and a $24 \mathrm{bp}$ downstream (antisense) primer DIS2 (5'CTCTCCTTCTAGCCTCCGCTAGTC-3') based on published sequences. ${ }^{12}$ A 165-bp PCR fragment was generated after 30 cycles of PCR amplification. A $10 \mu \mathrm{l}$ sample of the PCR mixture was subjected to digestion with $B s s \mathrm{HII}$, which recognizes the sequence GCGCGC, found in HIV-1 subtype B but not E, and with ApaLI, which recognizes the sequence GTGCAC, found in HIV-1 subtype $\mathrm{E}$ but not B. ${ }^{12}$ Positive controls were known infected peripheral blood mononuclear cells of both subtypes.

\section{Histopathology}

All 50 lymph nodes were removed from the cervical and supraclavicular regions. Lymph node biopsies were sliced into $2-3 \mathrm{~mm}$ sections and fixed in $10 \%$ neutral-buffered formalin. After overnight fixation, the blocks were routinely processed and embedded in paraffin. Sections $(4 \mu \mathrm{m})$ from the paraffin blocks were stained with hematoxylin and eosin, and with Gram (Brown-Hopps), mucicarmine, periodic acidSchiff, Warthin-Starry, Gomori methenamine silver and Ziehl-Neelson stains to evaluate for infections. The histological findings were categorized according to Chadburn et $a l^{13}$ as one of explosive follicular hyperplasia (EFH), follicular involution, mixed EFH and follicular involution, or lymphocyte depletion. ' $\mathrm{EFH}$ ' is recognized by markedly hyperplastic, irregularly shaped follicles in both the cortex and medulla. 'Follicular involution' consists of small, hypocellular and frequently hyalinized follicles, with hyperplastic paracortical areas and prominent intrafollicular vessels. In 'lymphocyte depletion', there is a total absence of follicular areas and the paracortical zone, with prominence of the medullary cords and sinusoids. The pathologic evaluation of lymph nodes was based on the morphologic features described by O'Murchadha et $a l^{14}$ and scored as 'present' or 'absent'. The relative incidence of each feature in the HIV-positive and control groups was compared by using Fisher's exact probability test and $\chi^{2}$ test with Yates' correction. ${ }^{15}$

\section{Immunohistochemistry}

All HIV-positive lymph nodes and all control lymph nodes were examined. Sections $(4 \mu \mathrm{m})$ from formalin-fixed, paraffin-embedded tissue blocks 
were applied to slides coated with 3-amino-propylethoxysilane. The sections were dewaxed in xylene, treated with $3 \%$ hydrogen peroxide and rinsed in phosphate-buffered saline. Microwave antigen retrieval was performed in $10 \mathrm{mM}$ citrate buffer ( $\mathrm{pH}$ 6.0) for $10 \mathrm{~min}$ and slides were cooled at room temperature for $30 \mathrm{~min}$. The sections were then incubated with the primary antibody for $60 \mathrm{~min}$ at room temperature, followed by a biotinylated 'link' antibody for 30 min (undiluted; LSAB kit, Dako, Carpinteria, CA, USA), and then 10 min with streptavidin-peroxidase reagent (undiluted; Dako). Antibody binding was detected using diaminobenzidene as the chromogen. Three different antibodies to HIV were used to confirm the immunostainng results. Monoclonal antibodies for p24 gag protein were obtained from three sources: Dako, used at 1:4 dilution; Research Diagnostics Inc. (Flanders, NJ, USA), used at 1:2 dilution; and Dr T Sata (National Institute of Health, Japan), used at 1:2 dilution.

\section{In Situ Reverse Transcriptase-PCR (In Situ RT-PCR)}

All HIV-positive lymph nodes and all control lymph nodes were examined. The RT step was carried out first by combining $20 \mu \mathrm{l}$ of specific master mix containing $1 \times$ reaction buffer, $1 \mathrm{mM}$ of each dNTP, $1 \mathrm{U}$ of Rnasin, $1 \mu \mathrm{M}$ of antisense primer, $10 \mathrm{mM}$ of dithiothreitol and $1 \mathrm{U}$ of Superscript II enzyme (Gibco-BRL, Gaithersburg, MD, USA) in a sterile $1.5 \mathrm{ml}$ microcentrifuge tube held on ice. In situ PCR was then performed using $12.5 \mu \mathrm{M}$ of primers: SK38 (sense) (5'-ATA ATC CAC CTA TCC CAG TAG GAG AAA T), SK39 (antisense) (5'-TTT GGT CCT TGT CTT ATG TCC AGA ATG C), TN01 (sense) (5'-GGA AGT GAC ATA GCA GG) and TN02 (antisense) (5'CTA CAT AGT CTC TGA AGG G), $0.2 \mathrm{mM}$ of each dNTP, $0.15 \mathrm{U}$ of Taq DNA polymerase and $1 \times$ PCR buffer. Primers SK38 and SK39 contain sequences shared by subtypes B and E, while primers TN01 and TNO2 are specific for subtype E. ${ }^{16}$ The final volume was $15 \mu \mathrm{l}$ to allow the entire tissue section to be covered, following which a glass coverslip was added and sealed around the edge with clear nail polish to prevent drying. The amplification process was carried out using Hybaid in situ PCR thermocycler (Franklin, MD, USA) under the following conditions: $94^{\circ} \mathrm{C}$ for $30 \mathrm{~s}, 61^{\circ} \mathrm{C}$ for $1 \mathrm{~min}$ and $72^{\circ} \mathrm{C}$ for $1 \mathrm{~min}$, for 30 cycles. The coverslip was then removed and the slide washed in $2 \times$ SSC for 2 min and PBS for a further 2 min. Next, the sections were postfixed in freshly made $4 \%$ paraformaldehyde for $5 \mathrm{~min}$, dehydrated in graded alcohol and air-dried. Sections were then incubated overnight at room temperature with the biotinylated probe, TN03 (5'-ATC CTG GGA TTA AAT AAA ATA GTA AGA ATG TAT AGC CC) that hybridizes to the PCR reaction product. The TN03 probe was then visualized by tyramide amplification using the TSA-
Indirect ISH kit (NEN Life Science Products, UK) according to the manufacturer's protocol. Briefly, sections were blocked for $30 \mathrm{~min}$ in TNB buffer at room temperature, then incubated for $30 \mathrm{~min}$ in horseradish peroxidase-conjugated streptavidin, followed by $5 \mathrm{~min}$ in biotin tyramide solution. For visualization of the signal, sections were incubated for $30 \mathrm{~min}$ in horseradish peroxidase-conjugated streptavidin. Diaminobenzidine was used as the chromogen and hematoxylin as a counterstain.

\section{Double Labelling of Tissue Sections}

Since none of the control lymph nodes gave any positive signal for HIV, only the 25 HIV-positive lymph nodes were examined by a double labelling technique in order to determine the identity of HIVinfected cells. This technique was based on a previously described method. ${ }^{17}$ The first stain was for HIV gag p24 by immunohistochemistry or HIV RNA by in situ RT-PCR as described above. After washing, a second primary monoclonal antibody was applied, followed by an alkaline phosphataseconjugated goat anti-mouse IgG (Sigma, Singapore), used at 1:100 dilution, for $30 \mathrm{~min}$. Primary antibodies were CD1a (monoclonal; Immunotech, Brea, CA, USA), used at 1:4 dilution, CD3 (polyclonal; Dako), used at 1:150 dilution, CD14 (monoclonal; Novocastra, Newcastle, UK), used at 1:50 dilution, CD20 (monoclonal; Dako), used at 1:1000 dilution, CD45RO (monoclonal; Dako), used at 1:1000 dilution, S-100 protein (polyclonal; Dako), used at 1:200 dilution and p55 (monoclonal; Dako), used at 1:100 dilution. The slides were then washed in $\mathrm{NaHCO}_{3}$ ( $\mathrm{pH} 8.3$ ) for $10 \mathrm{~min}$, followed by a $40 \mathrm{~min}$ incubation period with the alkaline phosphatase substrate composed of $5 \mathrm{mg}$ fast BBN salt, $100 \mu \mathrm{l}$ dimethylformamide, $1000 \mu \mathrm{l}$ naphtholASMX alkaline phosphate solution (Sigma), $5 \mu \mathrm{l}$ levamisole $(1.0 \mathrm{M})$ and $4.9 \mathrm{ml}$ $0.1 \mathrm{M}$ Tris buffer $(\mathrm{pH} 8.2)$. The slides were then washed in tap water for $10 \mathrm{~min}$ and mounted. Controls included (a) reversal of the chromogens for reproducibility and (b) omission of the second primary monoclonal antibody to demonstrate that the second labelling system did not react with antibodies already present as part of the first step.

\section{Results}

\section{Patients}

The clinical data for the HIV-positive patients are presented in Table 1. Using the 1993 CDC revised classification system, 15 of the 25 HIV-seropositive cases $(60 \%)$ were in group A with a presenting symptom of persistent generalized lymphadenopathy; seven cases $(28 \%)$ were in group B; and three cases $(12 \%)$ were in group C. Patients in group B presented with lymphadenopathy and conditions as stated in Table 1, while group C patients showed 
Table 1 Clinicopathological data

\begin{tabular}{|c|c|c|c|c|c|}
\hline Patient no. & Age (years) & Sex & $C D C$ group $^{\mathrm{a}}$ & $\begin{array}{l}\text { Symptomatology at } \\
\text { the time of biopsy }\end{array}$ & Lymph node pathology \\
\hline $1-11$ & $\begin{array}{l}22,35,30,33,29,34,38 \\
25,13,21,36\end{array}$ & $\begin{array}{l}\mathrm{F}, \mathrm{F}, \mathrm{F}, \mathrm{F} \\
\mathrm{M}, \mathrm{M}, \mathrm{M}, \mathrm{M} \\
\mathrm{M}, \mathrm{M}, \mathrm{F}\end{array}$ & A & None & $\mathrm{EFH}$ \\
\hline $12-15$ & $15,46,43,50$ & $\mathrm{~F}, \mathrm{~F}, \mathrm{M}, \mathrm{M}$ & A & None & Mixed \\
\hline 16 & 34 & $\mathrm{M}$ & B & Trichiuriasis & Mixed \\
\hline 17,18 & 42,35 & $\mathrm{~F}, \mathrm{M}$ & $\mathrm{B}$ & Fever $>1$ month & Mixed \\
\hline $19-22$ & $30,50,28,31$ & $\mathrm{~F}, \mathrm{M}, \mathrm{F}, \mathrm{M}$ & $\mathrm{B}$ & Fever $>1$ month & Follicular involution \\
\hline 23 & 66 & M & $\mathrm{C}$ & $\begin{array}{l}\text { Pneumocystis carinii } \\
\text { pneumonia }\end{array}$ & Follicular involution \\
\hline 24 & 48 & $\mathrm{~F}$ & $\mathrm{C}$ & CNS cryptococcosis & Lymphocyte depletion \\
\hline 25 & 40 & $\mathrm{M}$ & $\mathrm{C}$ & Pulmonary TB & Lymphocyte depletion \\
\hline
\end{tabular}

a 1993 CDC classification system for HIV infection and AIDS surveillance:

$\mathrm{A}=$ asymptomatic or acute or persistent generalized lymphadenopathy; $\mathrm{B}=$ symptomatic, not $\mathrm{A}$ or $\mathrm{C}$ conditions; $\mathrm{C}=\mathrm{AIDS}$ indicator conditions; $\mathrm{EFH}=$ explosive follicular hyperplasia; mixed = explosive follicular hyperplasia and follicular involution.

Table 2 Comparison of morphologic features between lymph nodes from HIV and non-HIV cases

\begin{tabular}{|c|c|c|c|c|c|}
\hline \multirow{2}{*}{$\begin{array}{l}\text { Morphologic features } \\
\text { Giant cells }\end{array}$} & \multicolumn{2}{|c|}{$H I V$ cases $(\mathrm{n}=25)$} & \multicolumn{2}{|c|}{ Non-HIV cases $(\mathrm{n}=25)$} & \multirow{2}{*}{$\frac{\text { P-value }}{0.00002}$} \\
\hline & 16 & $64 \%$ & 1 & $4 \%$ & \\
\hline Mantle-zone loss & 18 & $72 \%$ & 9 & $36 \%$ & 0.023 \\
\hline Irregular follicles & 11 & $44 \%$ & 14 & $56 \%$ & 0.571 \\
\hline Follicle lysis & 16 & $64 \%$ & 20 & $80 \%$ & 0.345 \\
\hline Burnt-out follicles & 13 & $52 \%$ & 10 & $40 \%$ & 0.570 \\
\hline Monocytoid cells & 12 & $48 \%$ & 8 & $32 \%$ & 0.386 \\
\hline Epithelioid histiocytes & 8 & $32 \%$ & 7 & $28 \%$ & 1.000 \\
\hline Dermatopathic change & 2 & $8 \%$ & 4 & $16 \%$ & 0.667 \\
\hline Marked plasmacytosis & 4 & $16 \%$ & 1 & $4 \%$ & 0.348 \\
\hline Germinal center hemorrhage & 8 & $32 \%$ & 9 & $36 \%$ & 1.000 \\
\hline
\end{tabular}

AIDS indicators including tuberculosis, cryptococcosis and Pneumocystis carinii pneumonia. The HIV-infected patients included 12 females and 13 males with an age range of 15-66 years (mean age of 35.2 years and median age of 34 years). All cases of HIV infection were acquired by heterosexual contact and all were subtype E. The control group consisted of 10 female and 15 male patients with an age range of 7-68 years (mean age of 36 years and median age of 33 years). None of these patients tested positive for HIV.

\section{Histopathology}

The lymph node findings in 25 HIV-seropositive cases included $11(44 \%)$ of $\mathrm{EFH}$, seven $(28 \%)$ of mixed $\mathrm{EFH} /$ follicular involution, five $(20 \%)$ of follicular involution and two (8\%) of lymphocyte depletion. EFH was confined to group A, present in $11 / 15$ or $73 \%$ of patients. Lymphoid depletion was confined to group C, and was present in $2 / 3$ or $67 \%$ of cases. Patients in group B showed either mixed $\mathrm{EFH} /$ follicular involution $(3 / 7$ or $43 \%$ of cases) or follicular involution ( $4 / 7$ or $57 \%$ of cases). Specific lymph node biopsy findings are presented in Table 2. Two features that were significantly more frequent in HIV-seropositive cases were the presence of giant cells $(P=0.00002)$ and mantle-zone loss $(P=0.023)$. These giant cells varied in appearance (number and location of nuclei and/or the amount of cytoplasm), but most commonly included cells with multiple nuclei clustering in the central portion of the cytoplasm. They occurred predominantly in the interfollicular areas, but in a few cases were also identified within follicles. The presence of giant cells was not associated with any particular pattern of lymph node histology and was seen with all four patterns.

\section{Immunohistochemistry}

All lymph node sections from HIV subtype Einfected cases demonstrated HIV p24 gag protein reactivity mostly in clusters of cells in the paracortical region, but occasionally as scattered cells in the interfollicular region (Figure 1a and b). Only few p24-positive cells were found around the edges of germinal centers. Positive cells were most numerous in lymph nodes showing $\mathrm{EFH}$ or mixed EFH/ follicular involution, which were the majority of cases in this study. Nevertheless, HIV-positive cells were noted in all patterns of lymph node histology. 

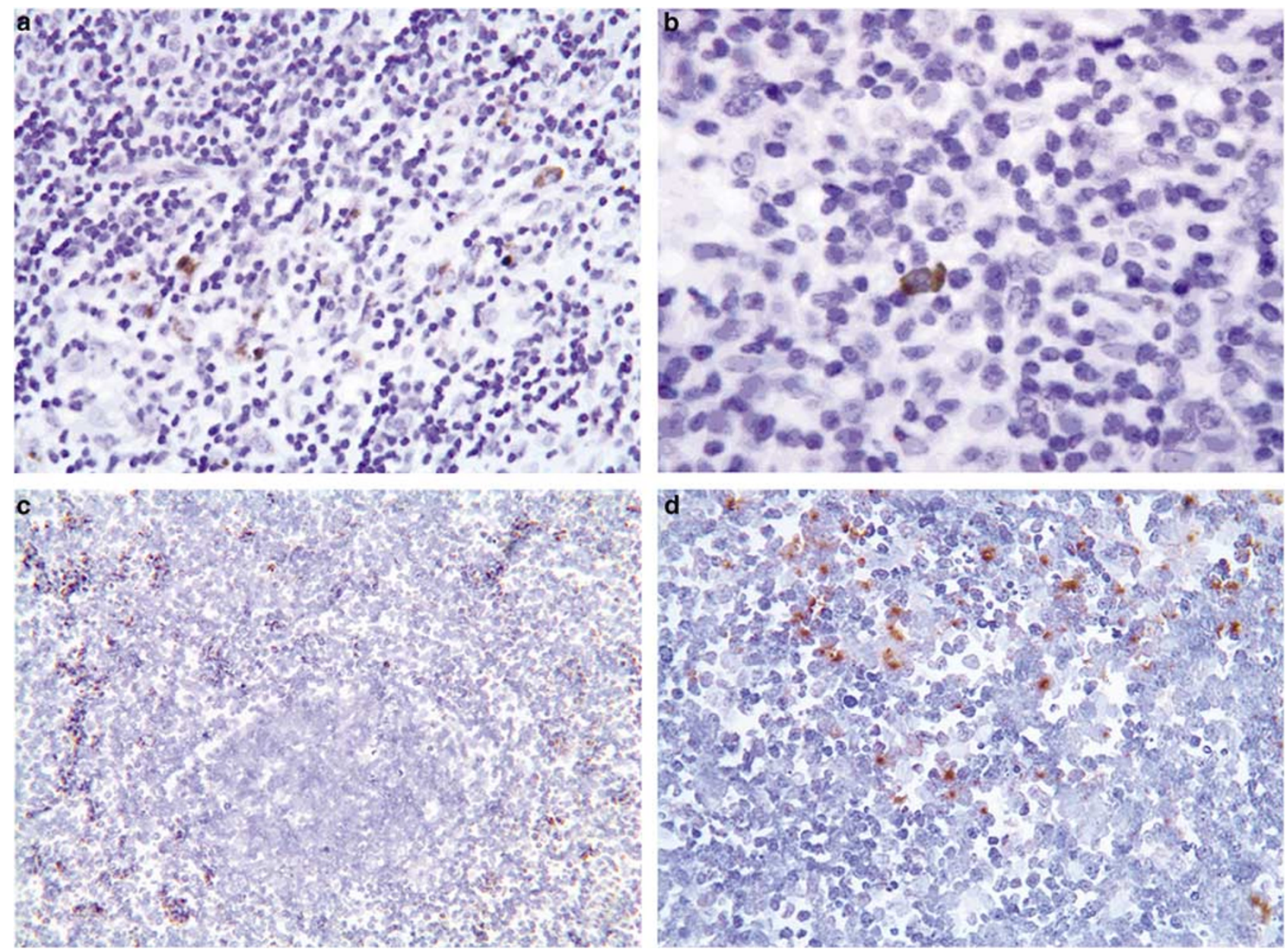

Figure 1 Detection of HIV-1 by immunoperoxidase staining for p24 (a and b) or RT-PCR (c and d). Expression was seen in clusters of cells in paracortical areas $(\mathbf{a} \times 250$; $\mathbf{d} \times 400)$, but only as individually scattered cells in the interfollicular region $(\mathbf{b} \times 250 ; \mathbf{c} \times 200)$ and rarely at all in germinal centers.

Only scattered positive cells were noted in lymph nodes showing lymphocyte depletion. There were no cases revealing a reticular pattern within germinal centers. A reticular pattern for HIV p24 gag protein reactivity had been noted by us previously in subtype B-infected lymph nodes. ${ }^{10}$ Some multinucleated giant cells were positive. Immunostaining for T-cell markers CD45RO and CD3 demonstrated a reduction or relative absence of $\mathrm{T}$ cells in the cases with follicular involution and lymphocyte depletion as compared with the EFH and mixed EFH/follicular involution patterns (results not shown).

\section{In Situ RT-PCR}

Positive cells were noted with all lymph node histology patterns. The most prominent HIV-RNA signals were located mainly in clusters of cells in the paracortex of lymph nodes (Figure 1c and d). Lymph nodes showing EFH or mixed EFH/follicular involution also expressed HIV-RNA in occasional cells around germinal centers and in interfollicular regions. Lymph nodes showing lymphocyte depletion and no germinal centers demonstrated scattered HIV-RNA signals throughout the lymph node.

\section{Identification of p24 and HIV-RNA-Positive Cells by Double Labelling}

By double labelling, those cells staining positively for p24 or for HIV-RNA that were present in the paracortical and interfollicular regions of HIV subtype E-infected lymph nodes were also positive for CD1a (Figure 2). There were also a few cells scattered at the edges of germinal centers, whereas the germinal centers were devoid of p24-positive or HIV-RNA-positive cells. The majority of p24immunopositive and HIV-RNA-positive cells in the interfollicular zone from HIV subtype E-infected lymph nodes were also positive for p55 and S-100 protein. About $10 \%$ of CD1a-positive cells were also positive for CD14. In the paracortical region, the HIV-positive cells were roughly an equal mixture of CD1a + S-100 + p55 + cells and CD3-positive cells. 

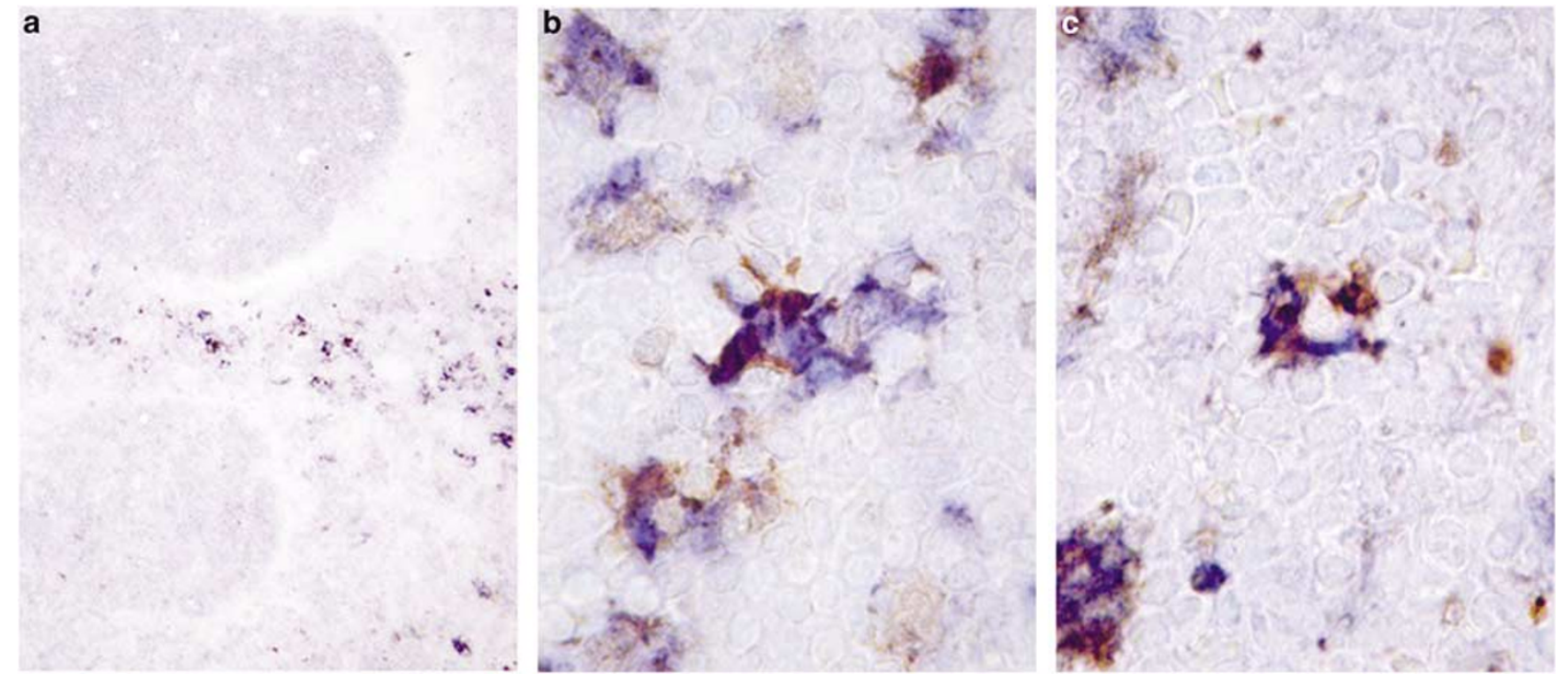

Figure 2 Identification of the HIV-infected cells as Langerhans histiocytes and related cells. Double immunohistochemistry (a and b) shows p24 (brown) is expressed in the cytoplasm of cells that are positive for CD1a (blue) in the interfollicular and paracortical regions of lymph nodes, whereas the germinal centers were devoid of such cells. Combined in situ RT-PCR and immunohistochemistry (c) shows cells that express HIV-RNA in the cytoplasm (brown) are also positive for CD1a (blue) $(\mathbf{a} \times 125$; $\mathbf{b}$ and $\mathbf{c} \times 1000)$.

Least common were the HIV-infected cells with a Warthin-Finkeldey-type giant cell morphology. These cells were also positive for S-100 protein, p55 and CD68. Not all cells of a given phenotype were positive for HIV-1. In lymph nodes from clinical group A (the majority of cases), $40-60 \%$ of the Langerhans cells and related histiocytes were infected with HIV, while $<30 \%$ of the T cells were. About $20 \%$ of the giant cells were HIV-positive. None of the HIV-positive cells marked as B cells.

\section{Discussion}

A major step in the pathogenesis of HIV infection is the localization of the virus in lymphoid organs following an initial viremia. The host is able to curtail viral replication but cannot eliminate the virus, leading to a chronic infection with a long period of clinical latency in which lymph nodes act as reservoirs for the virus. ${ }^{18-20}$ The virus appears to escape elimination by clonal deletion of specific cytotoxic lymphocytes and sequestration of these cells away from the sites of viral replication. Detection of virus and identification of viral reservoirs is important to a more complete understanding of the pathogenesis of this disease. Identification of the actual cells that are infected has been carried out using in situ RT-PCR to detect single copies of HIV-1 in infected cells. ${ }^{18,21-28}$ Previous in situ RT-PCR studies (presumably on subtype B) have localized the virus to lymph node germinal centres ${ }^{29-31}$ either as free virus $^{30}$ or in association with CD21+ follicular dendritic cells or macrophages, ${ }^{18,25,26,28-33}$ but not interdigitating dendritic cells. ${ }^{32}$ It has been proposed that CD4 + lymphocytes become infected as they contact follicular dendritic cells in transit through lymph node germinal centers. ${ }^{18,33}$ The result is a steady rate of $\mathrm{T}$-cell infection, and eventual depletion of $\mathrm{T}$ cells. Circulating CD4+ $\mathrm{T}$ cells contain the virus ${ }^{22,33}$ and can disseminate the infection systemically. The above sequence is based on subtype B and it is unclear whether the same events apply to other subtypes of HIV-1. To help elucidate this, we determined in this study the pathologic changes in lymph nodes in patients with subtype $\mathrm{E}$ infection together with identification of which cell types might be acting as reservoirs of the virus with this specific subtype.

The pathologic changes in lymph nodes from patients with different clinical stages of subtype $\mathrm{E}$ disease in northern Thailand tended to follow similar patterns to those noted for subtype B. Those who were asymptomatic usually showed follicular hyperplasia in lymph nodes, while symptomatic patients without full blown AIDS showed changes moving towards follicular involution. By the time the patients had AIDS, lymph nodes were showing follicular involution or lymphoid depletion. Among the several histologic features studied, only mantlezone loss and the presence of multinucleated giant cells were significantly more common in HIV cases as compared to the control cases. The most prominent difference was the multinucleated giants cells occurring in $64 \%$ of HIV-infected lymph nodes compared to $4 \%$ of control lymph nodes. The presence of giant cells has previously been reported in lymph nodes of HIV-seropositive patients, but only in a few cases. ${ }^{14,34-37}$ The giant cells were characterized by the nuclei clustered in the central portion or resembled Warthin-Finkeldey cells in some cases. These cells were not studied for the 
presence of HIV-1 nor immunophenotype. Giant cells have been reported in oropharyngeal lymphoid tissues from HIV-infected patients in early and latent stage of HIV infection. ${ }^{38-40}$ In the present study, we found giant cells in all clinical groups, not only in the pre-AIDS cases (clinical group A).

Our hypothesis was that Langerhans cells and related histiocytes serve as a reservoir of active virus in lymph nodes in cases of HIV-1 subtype E. This was based, in part, on the work of others who suggested that dendritic cells might be the initial target of HIV and a reservoir for the virus over time. ${ }^{41}$ In addition, previous in vitro work has shown that the HIV virus has the ability to replicate in epithelial Langerhans cells, and that subtype E replicates more readily than does subtype $B, 7,42$ although not all studies have confirmed this. ${ }^{43,44}$ Since epithelial Langerhans cell may be the first to encounter the virus after mucosal transmission, ${ }^{45}$ the ability of the virus to grow in these cells might enhance viral transmission and could help explain the epidemiologic findings of increased heterosexual transmission in Thailand and Southeast Asia.

Employing double labelling techniques, we found that there are different subsets of cells infected with HIV-1 subtype. The majority of HIV-infected cells in the lymph nodes were Langerhans cells that expressed CD1a and p55 and were located in the paracortical areas of lymph nodes with a few cells scattered at the edges of germinal centers. HIVinfected cells in the paracortex were roughly an equal mixture of $\mathrm{T}$ cells $(\mathrm{CD} 3+)$ and cells determined by morphology and immunophenotype to be interdigitating dendritic cells (S-100 + p55 + CD1a + ), which are Langerhans-related dendritic cells. ${ }^{38,46}$ The Warthin-Finkeldey-type giant cells were S-100+ p55 + CD68 + , also implying a relation to dendritic cells. ${ }^{47}$ Nonetheless, only $40-60 \%$ of the Langerhans cells and related histiocytes detected in the lymph nodes were actually infected with HIV-1 as detected by immunohistochemistry or RT-PCR, while $<30 \%$ of the $\mathrm{T}$ cells were. This result supports the notion that Langerhans cells are more readily infected with HIV-1, at least in the early stages of the disease, since in our study, the majority of the patients (15/25) were asymptomatic.

The evidence of the present study suggests that cells of the dendritic cell lineage are the main reservoirs of HIV subtype $\mathrm{E}$ in lymph nodes. HIV had previously been detected in Langerhans cells in situ, ${ }^{48}$ although it was not clear what role HIVinfected Langerhans cells might play in the pathogenesis of disease. In an earlier study, we tested the hypothesis that Langerhans cells and related histiocytes may constitute a reservoir for HIV subtype E in vaginal mucosa, based upon the known high transmissibility of subtype $\mathrm{E}$ by heterosexual contact. ${ }^{9}$ We found a significant increase in the number of Langerhans cells in vaginal epithelium of HIV subtype E-infected patients compared with the noninfected controls. Interestingly, a similar study from European patients, consisting primarily of nonE subtype infections, found an opposite result. ${ }^{49}$ Moreover, follicular dendritic cells have been found to be the main reservoir for subtype B HIV in the infected lymph nodes. ${ }^{10,26,50-53}$ We were unable to detect p24 staining within the follicular dendritic cell network of any of the subtype E HIV-infected lymph nodes in this study, although a small number of p24-positive cells were identified at the margins of some follicles.

Cells of the dendritic cell lineage are known to be potent antigen-presenting cells. Serving as sentinels for the immune system at various ports of entry, they capture antigens and subsequently stimulate T-cellassociated immunity. ${ }^{54,55}$ Dendritic cells, including interdigitating dendritic cells located in the T-cell zone of lymph nodes, regulate the activation of naïve $\mathrm{T}$ cells by efficiently processing and presenting immunogenic peptides in association with selfmajor histocompatibility complex molecules and by expressing either 'coreceptor' molecules or cytokines. ${ }^{56,57}$ The coreceptor CCR5 is a $\beta$-chemokine receptor that is preferentially used by HIV subtypes that infect macrophages. ${ }^{58}$ It is of interest to note that in our study about $10 \%$ of CD1a cells were also positive for CD14. Such cells are considered to reflect macrophage-derived dendritic cells, 10-25\% of which remain dually CD1a $+\mathrm{CD} 14+$ following maturation. ${ }^{59}$ These cells are high expressors of $\beta$ chemokines that can be inhibitory or stimulatory to HIV replication. ${ }^{58,60}$ Since cells of the dendritic cell lineage appear to be the main reservoirs of HIV subtype E, it would be of interest to do further investigations (such as triple staining) to determine to what extent the CD1a+CD14+ cells were infected by HIV compared to other CD1a-positive cells.

Frankel and co-workers discovered giant cells containing HIV genome and p24 antigen within or just beneath the mucosa of adenoid lymphoid tissue from asymptomatic HIV-1-infected patients. ${ }^{40}$ This observation suggests the possibility that HIV may be replicating in T-cell-dendritic cell complexes or syncytia, even in asymptomatic patients. It also suggests the possibility that HIV-infected mucosal dendritic cells may propagate the infection as they interact with $\mathrm{CD} 4+\mathrm{T}$ cells. A recent report ${ }^{61}$ documented that HIV-infected Langerhans cells appear preferentially to transmit infection to memory $\mathrm{T}$ cells, as compared with naive CD4+ $\mathrm{T}$ cells. Proliferating HIV-infected CD4 + memory $\mathrm{T}$ cells were frequently detected in conjugates of Langerhans cells and autologous CD4 + T cells, suggesting that $\mathrm{T}$ cells may become infected through cluster formation and interaction with infected Langerhans cells, rather than through encounter with free virus released by infected Langerhans cells or $\mathrm{T}$ cells. In this context, the observation in our study that the giant cells also shared dendritic markers and were p55 positive is of interest. Together, these findings highlight that close inter- 
actions between Langerhans cells, related dendritic cells and $\mathrm{T}$ cells are important for effective HIV replication within specific subsets of CD4 + T cells.

In conclusion, Langerhans cells and related cells are possibly both the initial targets and the long-term reservoirs for HIV subtype $\mathrm{E}$ infection following sexual (ie, mucosal) exposure to virus. Disrupting this pathway and the interaction between Langerhans cells, related dendritic cells and $\mathrm{T}$ cells may be a possible strategy to interfere with transmission of HIV subtype E.

\section{Acknowledgements}

This work was supported by the Thailand National Center for Genetic Engineering and Biotechnology (BIOTEC). We wish to thank Ms Lukana Eianleng and Ms Kaneungnit Likitwannawut for their excellent technical assistance.

\section{References}

1 Kanki P, Hamel D, Sankale J, et al. Human immunodeficiency virus type 1 subtypes differ in disease progression. J Infect Dis 1999;179:68-73.

2 Weniger B. Experience from HIV incidence cohorts in Thailand: Implications for HIV vaccine efficacy trials. AIDS 1994;8:1007-1010.

3 Weniger $\mathrm{B}$, Takebe $\mathrm{Y}$, Ou C, et al. The molecular epidemiology of HIV in Asia. AIDS 1994;8:S13-S28.

4 Young N, Shaffer N, Chaowanachan T, et al. Early diagnosis of HIV-1-infected infants in Thailand using RNA and DNA PCR assays sensitive to non-B subtypes. J Acquir Immune Defic Syndr 2000;24:401-407.

5 Kunanusont C, Foy H, Kreiss J, et al. HIV-1 subtypes and male-to-female transmission in Thailand. Lancet 1995;345:1078-1083.

6 Mastro T, de Vincenzi I. Probabilities of sexual HIV-1 transmission. AIDS 1996;10:S75-S82.

7 Soto-Ramirez L, Renjifo B, McLane M, et al. HIV-1 Langerhans' cell tropism associated with heterosexual transmission of HIV. Science 1996;271:1291-1293.

8 Mastro T, Satten G, Nopkesorn T, et al. Probability of female-to-male transmission of HIV-1 in Thailand. Lancet 1994;343:204-207.

9 Bhoopat L, Eiangleng L, Rugpao S, et al. In vivo identification of Langerhans and related dendritic cells infected with HIV-1 subtype E in vaginal mucosa of asymptomatic patients. Mod Pathol 2001;14:12631269.

10 Bhoopat L, Rithaporn T, Lekawanvijit S. Different localization of dendritic cell reservoirs in human immunodeficiency virus-1 subtype B vs subtype E-infected lymph nodes. Appl Immunohistochem Mol Morphol 2003;11:144-148.

11 Levy J. HIV and the Pathogenesis of AIDS, 2nd edn. ASM Press: Washington, DC, 1998.

12 St Louis D, Gotte D, Sanders-Buell E, et al. Infectious molecular clones with the nonhomologous dimer initiation sequences found in different subtypes of human immunodeficiency virus type 1 can recombine and initiate a spreading infection in vitro. J Virol 1998;72:3991-3998.

13 Chadburn A, Metroka C, Mouradian J. Progressive lymph node histology and its prognostic value in patients with acquired immunodeficiency syndrome and AIDS-related complex. Hum Pathol 1989;20: 579-587.

14 O’Murchadha M, Wolf B, Neiman R. The histologic features of hyperplastic lymphadenopathy in AIDSrelated complex are nonspecific. Am J Surg Pathol 1987;11:94-99.

15 Siegel S, Castellan Jr N. Nonparametric Statistics for the Behavioral Sciences, 2nd edn. McGraw-Hill: New York, 1988.

16 Quiros E, Garcia F, Gonzalez I, et al. Diagnosis of HIV-1 infection by PCR with two primer pairs. Eur J Epidemiol 1993;9:426-429.

17 Hofman F, Modlin R, Bhoopat L, et al. Distribution of cells bearing the Tac antigen during ontogeny of human lymphoid tissue. J Immunol 1985;134: 3751-3755.

18 Embretson J, Zupancic M, Ribas J, et al. Massive covert infection of helper T lymphocytes and macrophages by HIV during the incubation period of AIDS. Nature 1993;362:359-362.

19 Pantaleo G, Fauci A. New concepts in the immunopathogenesis of HIV infection. Annu Rev Immunol 1995;13:487-512.

20 Pantaleo G, Fauci A. Immunopathogenesis of HIV infection. Annu Rev Microbiol 1996;50:825-854.

21 Pezzella M, Rossi P, Lombardi V, et al. HIV viral sequences in seronegative people at risk detected by in situ hybridisation and polymerase chain reaction. BMJ 1989;298:713-716.

22 Bagasra O, Seshamma T, Oakes J, et al. Frequency of cells positive for HIV-1 sequences assessed by in situ polymerase chain reaction. AIDS 1993;7(Suppl 2): S7-S10.

23 Bagasra O, Pomerantz R. Human immunodeficiency virus type I provirus is demonstrated in peripheral blood monocytes in vivo: a study utilizing an in situ polymerase chain reaction. AIDS Res Hum Retroviruses 1993;9:69-76.

24 Nuovo G, Forde A, MacConnell P, et al. In situ detection of PCR-amplified HIV-1 nucleic acids and tumor necrosis factor cDNA in cervical tissues. Am J Pathol 1993;143:40-48.

25 Patterson B, Till M, Otto P, et al. Detection of HIV-1 DNA and messenger RNA in individual cells by PCRdriven in situ hybridization and flow cytometry. Science 1993;260:976-979.

26 Embretson J, Zupancic M, Beneke J, et al. Analysis of human immunodeficiency virus-infected tissues by amplification and in situ hybridization reveals latent and permissive infections at single-cell resolution. Proc Natl Acad Sci USA 1993;90:357-361.

27 Nuovo G, Gallery F, MacConnell P, et al. In situ detection of polymerase chain reaction-amplified HIV1 nucleic acids and tumor necrosis factor-alpha RNA in the central nervous system. Am J Pathol 1994;144: 659-666.

28 Peng H, Reinhart T, Retzel E, et al. Single cell transcript analysis of human immunodeficiency virus gene expression in the transition from latent to productive infection. Virology 1995;206:16-27.

29 Biberfeld P, Chayt K, Marselle L, et al. HTLV-III expression in infected lymph nodes and relevance to 
pathogenesis of lymphadenopathy. Am J Pathol 1986; 125:436-442.

30 Fox C, Tenner-Racz K, Racz $\mathrm{P}$, et al. Lymphoid germinal centers are reservoirs of human immunodeficiency virus type 1 RNA. J Infect Dis 1991;164: 1051-1057.

31 Brodie S. Nonlymphoid reservoirs of HIV replication in children with chronic-progressive disease. J Leukocyte Biol 2000;68:351-359.

32 Spiegel H, Herbst H, Niedobitek G, et al. Follicular dendritic cells are a major reservoir for human immunodeficiency virus type 1 in lymphoid tissues facilitating infection of CD4+ T-helper cells. Am J Pathol 1992;140:15-22.

33 Nuovo G, Becker J, Burk M, et al. In situ detection of PCR-amplified HIV-1 nucleic acids in lymph nodes and peripheral blood in patients with asymptomatic HIV-1 infection and advanced-stage AIDS. J Acquir Immune Defic Syndr 1994;7:916-923.

34 Domingo J, Chin N. Lymphadenopathy in a heterogeneous population at risk for the acquired immunodeficiency syndrome (AIDS)—a morphologic study. Am J Clin Pathol 1983;80:649-654.

35 Brynes R, Chan W, Spira T, et al. Value of lymph node biopsy in unexplained lymphadenopathy in homosexual men. JAMA 1983;250:1313-1317.

36 Joshi V, Oleske J, Minnefor A, et al. Pathology of suspected acquired immune deficiency syndrome in children: a study of eight cases. Pediatr Pathol 1984;2: 71-87.

37 Diebold J, Marche C, Audouin J, et al. Lymph node modification in patients with the acquired immunodeficiency syndrome (AIDS) or with AIDS related complex (ARC). A histological, immuno-histopathological and ultrastructural study of 45 cases. Pathol Res Pract 1985;180:590-611.

38 Wenig B, Thompson L, Frankel S, et al. Lymphoid changes of the nasopharyngeal and palatine tonsils that are indicative of human immunodeficiency virus infection. A clinicopathologic study of 12 cases. Am J Surg Pathol 1996;20:572-587.

39 Rinfret A, Latendresse H, Lefebvre R, et al. Human immunodeficiency virus-infected multinucleated histiocytes in oropharyngeal lymphoid tissues from two asymptomatic patients. Am J Pathol 1991;138: 421-426.

40 Frankel S, Wenig B, Burke A, et al. Replication of HIV1 in dendritic cell-derived syncytia at the mucosal surface of the adenoid. Science 1996;272:115-117.

41 Clark E. HIV: dendritic cells as embers for the infectious fire. Curr Biol 1996;6:655-657.

42 Rappersberger K, Gartner S, Schenk P, et al. Langerhans' cells are an actual site of HIV-1 replication. Intervirology 1988;29:185-194.

43 Pope M, Frankel S, Mascola J, et al. Human immunodeficiency virus type 1 strains of subtype B and E replicate in cutaneous dendritic cell-T-cell mixtures without displaying subtype-specific tropism. J Virol 1997;71:8000-8007.

44 Dittmar M, Simmons G, Hibbitts S, et al. Langerhans cell tropism of human immunodeficiency virus type 1 subtype A through $\mathrm{F}$ isolates derived from different transmission groups. J Virol 1997;71:8008-8013.

45 Spira A, Marx P, Patterson B, et al. Cellular targets of infection and route of viral dissemination after an intravaginal inoculation of simian immunodeficiency virus into Rhesus Macaques. J Exp Med 1996;183: 215-225.

46 Pinkus G, Pinkus J, Langhoff E, et al. Fascin, a sensitive new marker for Reed-Sternberg cells of Hodgkin's disease. Evidence for a dendritic or B cell derivation? Am J Pathol 1997;150:543-562.

47 Kapadia S, Wiley C, Soontornniyomkij V, et al. HIVassociated Waldeyer's ring lymphoid hyperplasias: characterization of multinucleated giant cells and the role of Epstein-Barr virus. Hum Pathol 1999;30: 1383-1388.

48 Zambruno G, Giannetti A, Bertazzoni U, et al. Langerhans cells and HIV infection. Immunol Today 1995;16:520-524.

49 Spinillo A, Tenti P, Zappatore R, et al. Langerhans' cell counts and cervical intraepithelial neoplasia in women with human immunodeficiency virus infection. Gynecol Oncol 1993;48:210-213.

50 Fox C, Cottler-Fox M. The pathobiology of HIV infection. Immunol Today 1992;13:353-356.

51 Pantaleo G, Graziosi C, Demarest J, et al. HIV infection is active and progressive in lymphoid tissue during the clinically latent stage of disease. Nature 1993;362: 355-358.

52 Haase A, Henry K, Zupancic M, et al. Quantitative image analysis of HIV-1 infection in lymphoid tissue. Science 1996;274:985-989.

53 Reinhart T, Rogan M, Viglianti G, et al. A new approach to investigating the relationship between productive infection and cytopathicity in vivo. Nat Med 1997;3:218-221.

54 Steinman R. The dendritic cell in clinical immunology: the AIDS example. J Lab Clin Med 1996;128: 531-535.

55 Hoefsmit E. Dendritic Cells in Fundamental and Clinical Immunology. Plenum Press: New York, 1993.

56 Cella M, Scheidegger D, Palmer-Lehmann K, et al. Ligation of CD40 on dendritic cells triggers production of high levels of interleukin-12 and enhances $\mathrm{T}$ cell stimulatory capacity: T-T help via APC activation. J Exp Med 1996;184:747-752.

57 Sallusto F, Cella M, Danieli C, et al. Dendritic cells use macropinocytosis and the mannose receptor to concentrate macromolecules in the major histocompatibility complex class II compartment: downregulation by cytokines and bacterial products. J Exp Med 1995; 182:389-400.

58 Kedzierska K, Crowe S, Turville S, et al. The influence of cytokines, chemokines and their receptors on HIV-1 replication in monocytes and macrophages. Rev Med Virol 2003;13:39-56.

59 Zou W, Borvak J, Marches F, et al. Macrophage-derived dendritic cells have strong Th1-polarizing potential mediated by b-chemokines rather than IL-12. J Immunol 2000;165:4388-4396.

60 Wang H, English N, Reid C, et al. Role of betachemokines in HIV-1 infection of dendritic cells maturing from CD34+ stem cells. J Acquir Immune Defic Syndr 1999;21:179-188.

61 Sugaya M, Lore K, Koup R, et al. HIV-infected Langerhans cells preferentially transmit virus to proliferating autologous CD4+ memory $\mathrm{T}$ cells located within Langerhans cell-T cell clusters. J Immunol 2004;172:2219-2224 